\section{NATURAL HISTORY OF SCRUB TYPHUS*}

\section{$\mathrm{T}$} HE work of the last ten years on diseases of the typhus group has permitted us to understand certain sides of them much more clearly. It is now known that there is one disease of this group widely spread in eastern Asia, transmitted from rodents to man by what we should call harvest mites. It should be known as 'scrub typhus' or alternatively as 'miteborne typhus'. No good general account of it, particularly from the entomological side, is available in print. The disease is of considerable importance in the British Empire.

The natural history of the disease is complex, and it may be best to approach it by setting down what is known about the so-called 'harvesters' of Britain and northern Europe. They are the larvæ of Trombicula autumnalis; the so-called 'chiggers' of North America are closely related. These larvæ, which are a fraction of a millimetre long, attach themselves to the skin of rodents, man, birds, etc., and hold on for several days. They drop into the soil, moult to become a nymph, moult again to become an adult and the female then lays eggs. Our knowledge of the life-history in the soil is fragmentary, but it seems to be established that the nymph and adult are vegetarian or that they feed on decomposing organic material. It seems that there is only one species in Britain, and it is probable that there is only one generation in the year. It is known that the rabbit and the bank vole are important hosts of the larva. On the bank vole, larvæ are common in late summer and autumn and after that diminish through the winter, to fall to a minimum in June. The species occurring in Britain seems to be localized to light soils, particularly those which are chalky, and the distribution is often extremely patchy. It seems probable that, by applying methods worked out for problems of soil entomology, much might be learned about the biology of this animal.

In attaching itself to the mammal, the larval Trombicula ejects a digestive juice which causes an area of hyaline degeneration: this often takes the form of a sharply defined column, vertical to the skin. Nothing is felt at the time when the larval mite is puncturing the skin; but some hours later irritation develops in some, but not all, human beings. The irritation may be quite serious, particularly to troops living in the field.

In south-east Asia there are many genera and species of Trombiculid mites, and the larvæ of a considerable number of them attack man. Rodents are certainly important hosts, and the natural history of scrub typhus is very complex because of the variety of rodents in this part of the world.

The larvie are important because they transmit the infectious agent producing the disease we call scrub typhus. The earlier work was mostly Japanese and showed that the larva of Trombicula akamushi feeds normally on voles (Microtus) on alluvial soils. It transmits infection from vole to vole or vole to man. As the mite only feeds on a mammal once in its life-history, the infection must be hereditary, and the virus has actually been recovered from wild adult mites. A similar or identical infection, always transmitted by larvæ of Trombicula, is known or believed to occur in the great triangle bounded by Japan, New

* Substance of a Friday discourse at the Royal Institution delivered by Prof. P. A. Buxton, F.R.S., on April 27.
Guinea and northern Queensland, Ceylon and the Maldives. Within this great area the disease may occur under exceedingly different environmental conditions, for example, in oquatorial forest, or in grassland, or on barren islets and atolls.

In man the disease is generally serious. There is a small ulcer at the site of attachment of the larval mite, high fever and a considerable mortality. The disease is widely distributed over the area of southeast Asia, and as men are living and fighting in jungle, it has proved much more common than generally expected. It tends to be highly localized and to produce occasional outbreaks with a very variable but serious death-rate.

\section{CONFERENCE ON X-RAY ANALYSIS*}

$\mathrm{T}$ THE second Annual Conference of the X-Ray Analysis Group of the Institute of Physics, and the fourth Conference on X-Rays in Industry which the Institute has arranged, was held in London at the Royal Institution during April 12-13. The Conference was an open one, and the attendance was about two hundred and fifty. The chairman, Sir Lawrence Bragg, opened by thanking the Royal Institution for the use of its premises, and welcomed scientific visitors from the Continent, who for the first time were able to be present at the Conference. Speaking of the X-Ray Analysis Group, Sir Lawrence reported briefly on its work during the past year. It now has 187 members, and in addition to its annual conference it held a meeting in Leeds last November on the performance of X-ray tubes. The committee has also produced recommendations for the design and dimensions of a standard powder camera ${ }^{1}$, and has in hand the revision and reproduction of Beevers-Lipson strips for Fourier analysis. It was hoped that the Group might sponsor the publication of a journal for papers on the atomic structure of matter and allied subjects. The chairman, secretary-treasurer, and ten members of committee of the Group were declared elected, in the absence of further nominations. A warm vote of thanks was made to Dr. Lipson for his work for the Group since its formation; his place as honorary secretary-treasurer is to be taken by Mr. F. A. Bannister (Minerals Department, Natural History Museum, Cromwell Road, London, S.W.7).

\section{Absolute Values of X-Ray Wave-Lengths}

At the Conference in 1943, the question of correcting X-ray wave-lengths, which were known to be in error by about 0.2 per cent, was left until the conversion factor might be more accurately known and international agreement might be reached as to its value. As these conditions are now at least partially fulfilled, the meeting considered further steps to be taken. Dr. Lipson said that there are three possibilities : to recommend immediately a value of the conversion factor, to leave the determination of the conversion factor to Prof. M. Siegbahn and the Americans who have worked on it, or to continue to use the old wave-lengths and await further developments. Of these he prefers the first.

\footnotetext{
* Report prepared by Audrey M. B. Parker, A. R. Stokes and A. J. C. Wilson.
} 